\title{
Municipalismo Atuante
}

O

espirito municipalista é, hoje, entre nós, uma das fôrças de maior evidência e de mais vigorosa atuação politica. Até bem pouco tempo, entretanto, o municipalismo, no Brasil, era uma simples tese. Não chegava a constituir, sequer, um movimento de opinião, tão poucas as pessoas que por êle se interessavam e tão frios os processos postos a seu serviço. Faltava-lhe a flama do entusiasmo e do arrôjo, a aptidão para transpor as paredes dos gabinetes e mergulhar no tumulto das ruas com êsse calor emocional que dá fibra ao pensamento e transforma a idéia num estimulo à ação.

Foi somente quando em seu derredor se reuniu uma equipe de jovens estudiosos dos problemas brasileiros de administração que êle adquiriu consciênciá de seu valor e da importância do papel que the cabia representar no processo de nossa evolução politica. A poucos foi dado o privilégio de assistir aos primeiros esforços com que êsse grupo de jovens se lançou à desencorajante tarefa de convencer os descrentes, reconquistar os desiludidos e criar novos entusiastas do municipalismo.

Rarás vêzes nossa mocidade deu uma tão expressiva demonstração de sua capacidade para o apostolado civico; raras vêzes soube tão bem impedir que o fascinio das idéias thes desviasse os olhos da realidade.

A leitura dos documentos máis caracteristicos do moderno municipalismo brasileito, como a Carta dos Municipios e as diversas Operações, revela uma técnica inteiramente nova, uma concepção larga e dinâmica na maneirá de encarar os problemas de nossas comunas. Sem romper com o passado, mas, ao contrário, cultuando e divulgando a obra dos pioneiros, os jovens municipalistas de hoje vêm semeando pelo Brasil afora uma nova mentalidade de administração e de govêrno. Para êles, o municipálismo é menos um tema para debates do que um instrumento de ação politico-administrativa que deve atingir as grandes massas populares, para interpretar-lhes os anseios e dar-lhes soluções adequadas. Com êles o municipalismo lançou-se à praça pública, 
em busca do homem do povo, para ser discutido, compreendido e aceito não como uma simples mensagem teórica, mas como uma fôrça atuante, capaz de ajudar a consolidar as bases do nosso sistema democrático. Graças a êles se realizam, periodicamente, grandes conclaves que permitem ao Brasil contemplar-se de corpo inteiro no espelho dos depoimentos que, de tôda parte, lhe trazem os prefeitos, vereadores e os estudiosos dos problemas do Municipio. Com isso se está fortalecendo o sentimento de união nacional e desenvolvendo entre os lideres do nosso interior a prática da cooperação, o intercâmbio das idéias e a preocupação pelos processos da administração racional.

O caráter educativo do moderno municipalismo brasileiro é, ainda, marcado acentuadamente, por várias outras iniciativas como a publicação de um jornal dedicado à divulgação dos assuntos de interêsse pára os municipios, a edição de obras especializadas nas questóes referentes ao govêrno local e um ativo serviço de assessoria técnica aos prefeitos e câmaras de vereadores.

O D.A.S.P., que mantém com o moderno movimento municipalista vários pontos de contato, que o tem estimulado de diversas formas e que nêle deposita fundadas esperanças, vê com grande jübilo seu crescente prestigio. 